\title{
The Use of the Data Envelopment Analysis Method in the Assessment of Enterprises with Credit Risk*
}

\begin{abstract}
Anna Feruśs*
Abstract: The subject of the present article is a new procedure forecasting the credit risk of companies in the Polish economy environment. The suggestion is strongly supported by the fact that so far the DEA method has not been applied to estimate the credit risk of companies within the framework of credit-scoring. The research described in the article has been conducted on the basis of a comparison of the suggested DEA method with currently used procedures, namely the point method, discriminative analysis and linear regression. Considering the research, it can be concluded that the DEA method facilitates forecasting financial problems, including the bankruptcy of companies in Polish economic conditions, and its effectiveness is comparable or even greater than any approaches implemented so far.
\end{abstract}

Keywords: credit-scoring, credit risk, credit rating, Data Envelopment Analysis, technical effectiveness

\section{Implementing the DEA method in credit risk management}

The methodology of credit risk assessment with the use of the DEA ${ }^{1}$ method suggested below was prepared on the basis of literature studies (Emel et al. 2003: 103-123; Simak 2000: 1-189; Gospodarowicz 2004: 119-129) as well as the author's own research (Feruś 2006a: 44-59; Feruś 2006b: 245-253; Feruś 2006c: 263-269; Feruś 2007d: 225-233; Feruś 2007e: 144-154; Feruś 2008f: 196-215; Feruś 2008g: 153-160; Feruś 2008h: 109-118; Feruś 2009i: 221-231). It consists of five stages, as presented in Figure 1.

\footnotetext{
* The article presents results of the research conducted within research project \# H02B 01530 financed with educational sources.

** dr Anna Feruś, Politechnika Rzeszowska, Zakład Finansów i Bankowości, al. Powstańców Warszawy 10, 35-959 Rzeszów, e-mail: aferus@prz.edu.pl.

${ }^{1}$ The DEA method was first introduced in 1978 by American economists Charnes, Cooper and Rhodes. Relying on a productivity concept, formulated by G. Debreu (1951) and M.J. Farrel (1957), which defined effectiveness measured as quotient of a singular effect and singular set-up, they used it for a multidimensional situation in which there was more than one set-up as well as more than one effect. Using the DEA method, the effectiveness of an object is calculated in relation to other objects from a particular group. Effective objects within a particular group make the so-called effectiveness curve. The effectiveness of remaining objects are calculated in relation to the curve defined through solving the issue of linear programming (using the DEA method).
} 


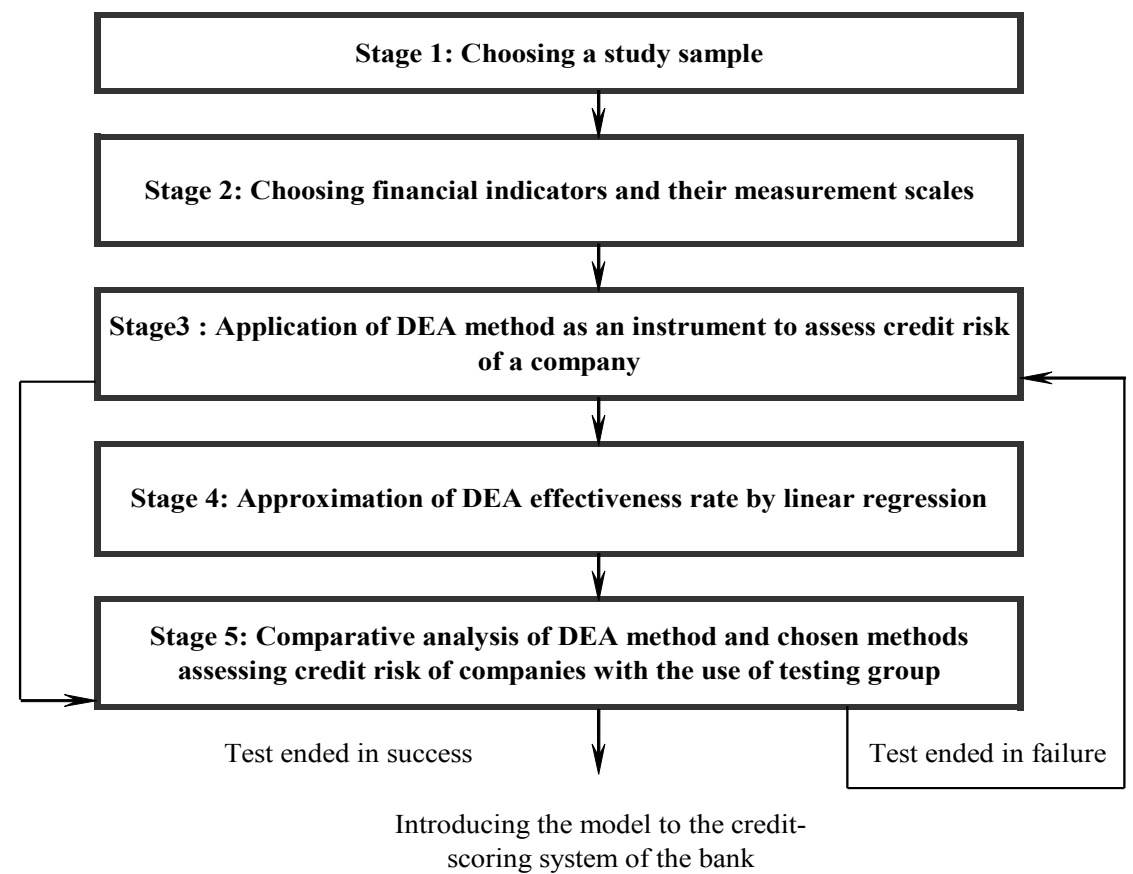

Figure 1. Suggested method of assessing the credit risk of companies, using the DEA method Source: self-study.

\section{Stage 1}

The basis of the study was a statistical one containing information provided by a bank on 100 construction companies that obtained a credit loan in the years 2001-2003. This study included the status of credit repayment history ${ }^{2}$.

\section{Stage 2}

The analysis was conducted for a one year period as well as two years before considering the firms as being bankrupt. The study used 22 financial indicators. Next, based on correlation assumption 6 indicators were chosen (Table 1) that did not contain any information provided by other financial indicators from this study, but at the same time were good representative indicators that were not chosen for the diagnosis ${ }^{3}$.

\footnotetext{
${ }^{2}$ Statistical matter contained 50 solvable firms and 50 firms with a delinquency risk

${ }^{3}$ Chosen indicators were weakly correlated with each other and strongly correlated with fluctuating alignment.
} 


\section{Table 1}

Financial indicators used in the study

\begin{tabular}{ll}
\hline $\begin{array}{l}\text { Indicator's } \\
\text { symbol }\end{array}$ & Indicator's formula \\
\hline$X_{1}$ & $\begin{array}{l}\text { Net profit indicator }=(\text { financial result } \times 100) /(\text { profit from sales and equals }+ \text { other operation } \\
\text { profits }+ \text { financial profits })\end{array}$ \\
$X_{2}$ & Asset return indicator $($ ROA net $)=($ financial result $\times 100) /$ total of assets \\
$X_{3}$ & Individual assets return indicator $($ ROE net $)=($ net financial result $\times 100 \times 12 / \mathrm{n}) /$ individual assets \\
$X_{4}$ & Current liquid indicator $=$ revolving capital $/$ short term debts \\
$X_{5}$ & Daily return indicator $=($ total of return $\times \#$ of days $) /($ profit from sales and equals + other operation \\
& profits + financial profits $)$ \\
$X_{6}$ & General debt indicator $=($ general debts $\times 100) /$ total return \\
\hline
\end{tabular}

Source: self-study.

\section{Stage 3}

A crucial problem in this stage is the choice of the right set ups and effects used in firms' component. Assignment of the individual financial indicators to groups of set ups and effects depends mainly on problem format. Often the scripts on the studied object indicate five basic ways to define set up and effect: producer concept, financial agent concept, financial asset concept, summarized value concept and user expense concept. The solution of a given problem based on the DEA method depends on choosing the right DEA model. To classify the DEA model two criteria must be present simultaneously: type of effect scale and orientation of the model. The first criterion defines what theories were applied to the effect scale in the model (variable (VRS), constant (CRS) or not rising (NIRS)). The second factor demonstrates whether set ups are minimized or if the effects are maximized. Depending on the choice of the model orientation, what can be calculated is either the technical effectiveness of set up or technical effectiveness oriented on the solution or so called undirected models.

Based on a thorough literature study (Emel et al. 2003: 108-121; Simak 2000: 43-100; Gospodarowicz 2004: 123-129), credit inspectors' interview and personal experiences (Feruś 2006a: 44-59; Feruś 2006b: 245-253; Feruś 2006c: 263-269; Feruś 2007d: 225-233, Feruś 2007e: 144-154; Feruś 2008f: 196-215; Feruś 2008g: 153-160; Feruś 2008h: 109-118; Feruś 2009i: 221-231) in that aspect, set up and effect classifications were created ${ }^{4}$ :

- set ups: $X_{5}$ and $X_{6}$,

- effects: $X_{1}, X_{2}, X_{3}$ and $X_{4}$.

To calculate the technical effective indicator value of the studied firms the CCR (constant scale effect) model was used. This was directed toward set ups with a search for a minimal value of effectiveness indicator that will possibly reduce the amount of set up and result in the equal effect of the study object. For this calculation the optimal linear program $\mathrm{EMS}^{5}$

\footnotetext{
${ }^{4}$ The author used numerous studies examining the model effectiveness. The present article provides the final model that proved to be the most effective in determining the firms' credit risk factor.

${ }^{5}$ Dortmund University website sources: http://wiso.unidortmund.de/LSFR/OR/scheel/ems.
} 
was used. The effectiveness indicator results for each firm in the study ranged from 0 to 1 . The value of the effectiveness indicator equal to 1 demonstrates the firm being effective whereas, the effectiveness indicator value which is lower than 1 demonstrates the firm has an opportunity to improve the relations of set ups and effects - indicates effectiveness loss level.

In this part of the study research was also aimed at finding the base point (cut off point) of the effectiveness coefficient that will separate the solvent group of firms from the firms with the risk of delinquency.

A good concept, allowing for setting the right base point value, but also considering an incorrect object classification, was a study of interdependency between the value of incorrect classification and the value of the base point. In this approach, the optimal base point regulates the minimal entire cost of the incorrect classification. Moreover, this concept permits a multi variant analysis, the optimal base point change due to the incorrect classification of Type I or II. To show the entire cost of the incorrect classification the following formula was applied (Simak 2000: 94-95):

$$
T C=i(p) \cdot C_{1}+j(p) \cdot C_{2}
$$

where:

$C_{1}$ - loss indicator Type I error,

$C_{2}-$ loss indictor Type II error,

$i(p)$ - error quantity Type I,

$j(p)$ - error quantity Type II.

For the purpose of this study, $C_{1}$ and $C_{2}$ are equal to 0.6 and 0.03 respectively.

For the above mentioned CCR model (constant scale effect) concentrated on set ups, the effectiveness coefficient base value was verified for a year as well as two years before a delinquency level of below 0.40 . This indicates the 0.40 or lower rank implies a high risk of defaulting. Furthermore, 0.40 or higher rank implies a low risk of defaulting.

The DEA method classification effectiveness is illustrated in Table 2. In addition, the DEA method results (Table 2) were compared with the point method (MP) results as well as with regressive linear $(\mathrm{RL})$ results. Using the same material, the author was able to complete a credible comparative analysis using statistical data.

Based on the classification results shown in Table 2 it could be concluded that the effectiveness of I and II classification with the use of the DEA method is similar to a discriminating analysis and regressive linear regression. 
Table 2

Evaluation of different methods of effectiveness using 2001-2002 data $(\%)$

\begin{tabular}{llrllllll}
\hline Method & MP & & AD & & RL & \multicolumn{3}{l}{ DEA } \\
\hline Base point & - & & 0 & & 0.5 & & 0.4 & \\
\hline \multirow{2}{*}{2001} & $S_{2}$ & 100 & $S_{2}$ & 96 & $S_{2}$ & 96 & $S_{2}$ & 90 \\
& $S_{1}$ & 58 & $S_{1}$ & 80 & $S_{1}$ & 80 & $S_{1}$ & 72 \\
& $S$ & 79 & $S$ & 88 & $S$ & 88 & $S$ & 81 \\
\hline \multirow{3}{*}{2002} & $S_{2}$ & 100 & $S_{2}$ & 90 & $S_{2}$ & 90 & $S_{2}$ & 80 \\
& $S_{1}$ & 70 & $S_{1}$ & 86 & $S_{1}$ & 86 & $S_{1}$ & 84 \\
& $S$ & 85 & $S$ & 88 & $S$ & 88 & $S$ & 82 \\
\hline
\end{tabular}

Source: self-study.

\section{Stage 4}

The main purpose of this phase is an attempt at reducing the DEA method fallacy caused by the necessity of applying an optimal linear program for every study of a firm applying for a credit loan (Simak 2000: 94-95). The suggested solution to this problem is the application of a regressive linear function that allows for finding a correlation between the coefficient DEA method value and its effectiveness with defined set ups and effects. In this case, the regressive linear function could be used as a linear estimation of the coefficient DEA method values without the need of the extensive process of the DEA method verification each time a new firm is applying for a credit. In other words, a regressive linear function could be used while determining the studied firm's credit risk level without going through the first three phases (Emel et al. 2003: 108-115). Accordingly, the regressive linear function was defined during the process of estimating the coefficient value of the DEA method of effectiveness. The past coefficient DEA method of effectiveness values through a regressive linear function were treated as a dependent variable $Y$ (endogenous variable), and the defined set up and effect were noted as an operand $X_{i}$ (exogenous variable). The regressive linear function research was conducted through using the Statistica 6.0 program. When rating the value of the regressive linear function model the level of significance $\alpha=0.05$ was established.

${ }^{6} S_{2}$-Type II Efficiency - determines what percentage of solvable firms was correctly classified $\left(S_{2}=\right.$ $P 2:(P 2+N P 2) \times 100 \%$, where $P 2$ - number of solvable firms classified as solvable group, $N P 2$ - number of solvable firms classified as a delinquency risk group), $S_{1}$ - Type I Efficiency - determines what percentage of firms with a delinquency risk was correctly classified $\left(S_{1}=P 1:(P 2+N P 1) \times 100 \%\right.$, where $P 1-$ number of firms with a risk of delinquency classified as a delinquency risk group, $N P 1$ - number of firms with risk of delinquency classified as solvable, $S$ - General Classification of Efficiency - determines what percentage of all firms was correctly classified with the application of the $(S=(P 1+P 2):(P 2+N P 2+P 2+N P 2) \times 100 \%)$. The base point value in the discrimination analysis model and regressive linear model was calculated as an average value from average of the groups. 
This is the final linear regression model formula:

$$
\begin{gathered}
Y_{\text {DEA_2001-2002 }}=-0.0006 X_{5}+0.0010 X_{6}+0.0826 X_{1}+ \\
\quad+0.0126 X_{2}-0.0003 X_{3}+0.2831 X_{4}+0.0564
\end{gathered}
$$

\section{Table 3}

Selected properties of regressive linear function $\mathrm{Y}_{\mathrm{DEA}}$

\begin{tabular}{lllllll}
\hline$R^{2}=67 \%, F(6 / 93)=31.46$ & $\mathrm{X}_{5}$ & $\mathrm{X}_{6}$ & $\mathrm{X}_{1}$ & $\mathrm{X}_{2}$ & $\mathrm{X}_{3}$ & $\mathrm{X}_{4}$ \\
\hline Variables & -4.82 & 2.32 & 3.64 & 2.62 & -2.13 & 6.57 \\
$t\left(a_{i}\right)$ & 0.0000 & 0.0227 & 0.0004 & 0.0102 & 0.0354 & 0.0000 \\
\hline
\end{tabular}

Source: self-study.

Summarizing the results of the above study (Table 3 - test of essence: t-Student, F-Snedecora, determining coefficient $R^{2}$ ) one can recognize that the choice of dependent variables in the regressive linear function $Y_{\mathrm{DEA}}$ is accurate. Furthermore, all the regressive linear function $Y_{\mathrm{DEA}}$ properties were statistically significant.

The efficient classification results in Table 4 in the regressive linear function Y DEA - 2001-2002 do not differ considerably from the DEA method results shown in Stage 3 of this study, which means that the equalization of the linear regression could be treated as the linear approximation of the coefficient DEA effectiveness value.

\section{Table 4}

Comparing the classification the effectiveness of DEA method with a regressive linear function $\mathrm{Y}_{\mathrm{DEA}}(\%)$

\begin{tabular}{lllll}
\cline { 2 - 5 } & \multicolumn{4}{l}{ Base point $=0.40$} \\
\cline { 2 - 5 } & DEA & \multicolumn{3}{l}{$Y_{\text {DEA }}$} \\
\cline { 2 - 5 } & 2002 & 90 & 2002 & 2001 \\
\hline$S_{2}$ & 80 & 72 & 86 & 86 \\
$S_{1}$ & 84 & 81 & 86 & 76 \\
$S$ & 82 & 86 & 81 \\
\hline
\end{tabular}

Source: self-study.

\section{Stage 5}

To check and verify the accuracy and effectiveness of the prognostic qualities of the above studied models, the statistic matter (100 firms) was divided equally $1: 1$ in respect to two separate research samples: controlled and placebo group. The effectiveness rate of both groups' classification is presented in Table 5. 


\section{Table 5}

Comparing the effectiveness of various methods for the placebo sample group using 2001-2002 data (\%)

\begin{tabular}{lllllll}
\hline Method & AD & & RL & \multicolumn{3}{l}{ DEA } \\
\hline Punkt progowy & 0 & & 0.5 & & 0.5 & \\
\hline \multirow{2}{*}{2001} & $S_{2}$ & 96 & $S_{2}$ & 96 & $S_{2}$ & 88 \\
& $S_{1}$ & 68 & $S_{1}$ & 68 & $S_{1}$ & 80 \\
& $S$ & 82 & & 82 & & 84 \\
\hline \multirow{2}{*}{2002} & $S_{2}$ & 88 & $S_{2}$ & 88 & $S_{2}$ & 84 \\
& $S_{1}$ & 80 & $S_{1}$ & 80 & $S_{1}$ & 96 \\
& $S$ & 84 & $S$ & 84 & $S$ & 84 \\
\hline
\end{tabular}

Source: self-study.

Based on the above classification results in Table 5 it can be determined that the DEA method has superior prognostic indicators. It best minimizes type I errors where classification effectiveness was higher than $12 \%$ two years before delinquency and higher than $16 \%$ one year before delinquency. However, a general classification of the effectiveness of the DEA method is similar to a general classification for methods: discrimination and linear regression analysis.

\section{Conclusions}

Founded by the study, it can be concluded that the DEA method correctly predicts the possible financial difficulties including a company's bankruptcy risk in the Polish economic situation. These results are comparable or even superior to other methods presently employed.

This study signifies the universal application of the DEA method in analysing a large spectrum of credit risk uncertainty. It not only measures efficiency in respect to the use of financial risk indicators, but it facilitates an accurate credit risk classification for corporations in the credit application process.

\section{References}

Emel A.B., Oral M., Reisman A., Yolalan R. (2003), A credit scoring approach for the commercial banking sector, "Socio-Econoimc Planning Sciences", vol. 37.

Feruś A. (2006a), Zastosowanie metody DEA do określania poziomu ryzyka kredytowego przedsiębiorstw, „Bank i Kredyt", nr 7.

Feruś A. (2006b), Określanie poziomu ryzyka kredytowego przedsiębiorstw z wykorzystaniem metody DEA, in: Problemy zarządzania finansami we współczesnych przedsiębiorstwach, ed. P. Szczepankowski, VIZJA PRESS, Warszawa.

Feruś A. (2006c), Szacowanie ryzyka kredytowego przedsiębiorstw z wykorzystaniem metody DEA, in: Finanse przedsiębiorstwa, ed. P. Karpuś, Wydawnictwo Uniwersytetu Marii Curie-Skłodowskiej, Lublin. 
Feruś A. (2007d), Szacowanie ryzyka kredytowego przedsiębiorstw ze szczególnym uwzględnieniem metody DEA, in: Harmonizacja bankowości i ubezpieczeń w skali narodowej i europejskiej, eds. M. Marcinkowska, S. Wieteska, Difin, Warszawa.

Feruś A. (2007e), Wykorzystanie metody DEA do oceny ryzyka kredytowego przedsiębiorstw $w$ ramach credit-scoringu, in: Zarzadzanie finansami firm - teoria i praktyka, ed. W. Pluta, Prace Naukowe Akademii Ekonomicznej we Wrocławiu nr 1152, Wrocław.

Feruś A. (2008f), УПРАВЛІННЯ КРЕДИТНИМИ РИЗИКАМИ ПІДПРИЕМСТВ ЗА ДОПОМОГОЮ МЕТОДУ DEA - Zarządzanie ryzykiem kredytowym przedsiębiorstw z zastosowaniem metody DEA, in: АКТУАЛЬНI ПРОБЛЕМИ УПРАВЛІННЯ - Aktualne problemy zarządzania: Монографія, t. 2, Запоріжжя-Жешув.

Feruś A. (2008g), Zarzadzanie ryzykiem kredytowym przedsiębiorstw z wykorzystaniem metody DEA $w$ ramach credit-scoringu, in: Zarządzanie finansami firm - teoria i praktyka, ed. B. Bernaś, Prace Naukowe Akademii Ekonomicznej we Wrocławiu nr 1200, Wrocław.

Feruś A. (2008h), The DEA metod in managing the credit risk of companies, "Ekonomika" vol. 84, Vilnius University, Vilnius.

Feruś A. (2009i), Zarządzanie ryzykiem kredytowym przedsiębiorstw z wykorzystaniem metody DEA w ramach credit-scoringu, in: Zarzadzanie finansami firm - teoria i praktyka, ed. B. Bernaś, Prace Naukowe Akademii Ekonomicznej we Wrocławiu nr 48, Wrocław.

Gospodarowicz A. (2004), Możliwości wykorzystania metody DEA do oceny ryzyka kredytowego w kontekście Nowej Umowy Kapitałowej, in: Przestrzenno-czasowe modelowanie i prognozowanie zjawisk gospodarczych, ed. A. Zeliaś, AE, Kraków.

Iwanicz-Drozdowska M. (2005), Zarzadzanie finansowe bankiem, PWE, Warszawa.

Simak P.C. (2000), Inverse and Negative DEA and their Application to Credit Risk Evaluation, Centre for Management of Technology and Enterpreneurship, Faculty of Applied Sciences and Engineering, University of Toronto, Toronto.

\section{WYKORZYSTANIE METODY DEA W OCENIE RYZYKA KREDYTOWEGO PRZEDSIĘBIORSTW}

Streszczenie. Celem artykułu jest zaproponowanie nowego postępowania prognozującego ryzyko kredytowe przedsiębiorstw w polskich warunkach gospodarczych, wykorzystującego metodę Data Envelopment Analysis (DEA). Za podjęciem proponowanych badań przemawia fakt, że dotychczas w naszym kraju nie podejmowano prób zastosowania metody DEA do szacowania ryzyka kredytowego przedsiębiorstw w ramach credit-scoringu. Badania w artykule były prowadzone na zasadzie porównania proponowanej metody DEA z metodami obecnie stosowanymi (tj. metoda punktowa, analiza dyskryminacyjna, regresja liniowa). Na podstawie przeprowadzonych badań można wnioskować, że metoda DEA umożliwia przewidywanie trudności finansowych, łącznie z zagrożeniem bankructwem przedsiębiorstw w polskich warunkach gospodarczych na poziomie porównywalnym lub nawet przewyższającym dotychczas stosowane metody.

Słowa kluczowe: credit-scoring, ryzyko kredytowe, zdolność kredytowa, DEA, efektywność techniczna

\section{Citation}

Feruś A. (2015), The Use of the Data Envelopment Analysis Method in the Assessment of Enterprises with Credit Risk, Zeszyty Naukowe Uniwersytetu Szczecińskiego nr 855, „Finanse, Rynki Finansowe, Ubezpieczenia” nr 74, t. 1, Wydawnictwo Naukowe Uniwersytetu Szczecińskiego, Szczecin, s. 493-500; www.wneiz.pl/frfu. 